\author{
L.F. Ilina, A.S. Kayumova, Ye.R. Zhangbyrbaj, M.M. Bolatbekova \\ Ye.A. Buketov Karaganda State University, Kazakhstan \\ (E-mail: aneka.08@mail.ru)
}

\title{
To modernization of physical practicum on molecular physics in the university course
}

\begin{abstract}
The article is devoted to analysis of the author's work results on the modernization of the physical practicum in Molecular Physics at the Department of physics and nanotechnologies of the physics and technical faculty. High-quality direction of such a physical practicum is impossible without the use of virtual laboratory work, but contact laboratory work is also necessary. Moreover, it is advisable to carry out some laboratory work both contact and virtually. This article presents the essence of work on gas laws and the definition of universal gas constant and Boltzmann constant; three virtual works on statistical physics and one contact laboratory work on transfer phenomena were analyzed. The works were preliminarily analyzed and carried out at the level of teachers and engineers, then by students, moreover of different groups both in the general physics course and in special courses of the corresponding profile. Graduate work and master's dissertation were carried out in some sections; reports were presented at conferences of different levels; published articles and educational and methodical materials.
\end{abstract}

Keywords: Maxwell distribution, Brownian motion, contact and virtual laboratory works, transfer phenomena.

The structure of the course of molecular physics at the university is as follows: an introduction to molecular physics, the definition of its content and features; molecular kinetic theory; its subject, method, characteristics; fundamentals of the statistical theory of ideal gases (mathematical apparatus, distribution; thermodynamics; transfer phenomena; real gases; molecular kinetic properties of liquids; solids; phase transitions) [1-4].

It is obvious that the physical practicum should be built and organized along the same structure. And this is not true.

Within the framework of one article, it is impossible to present the content of physical practicum in all sections of molecular physics. Let us stay on the first 3 blocks.

The first block includes 2 classical laboratory works: «Determination of the universal gas constant» and «Determination of the Boltzmann constant». These are contact laboratory works that are based on the equation of state of an ideal gas (the Mendeleev-Clapeyron equation) and the basic equation of the molecular-kinetic theory of ideal gases, namely, on one of its consequences, the pressure formula, i.e. 3 basic interconnected universal constants are immediately introduced: $\mathrm{R}$; $\mathrm{k}$ (Boltzmann constant) and $\mathrm{N}_{\mathrm{Av}}$ (Avogadro number).

The results we obtained (and the students), for example, are:

i.e. relative fault:

$$
R=(8.1 \pm 0.4) \frac{\mathrm{J}}{\mathrm{mol} \cdot \mathrm{K}},
$$

$$
\varepsilon=\frac{\Delta R}{R} \cdot 100 \% \cong 5 \% .
$$

Confidence interval: $(7.7-8.5) \mathrm{J} / \mathrm{mol} \cdot \mathrm{K}$.

Thus, the theoretical value $\mathrm{R}=8.31 \mathrm{~J} / \mathrm{mol} \cdot \mathrm{K}$ «fits» into the confidence interval.

Boltzmann's constant:

Relative fault:

$$
k=(1.2 \pm 0.2) \cdot 10^{-22} \frac{\mathrm{J}}{\mathrm{K}} .
$$

$$
\varepsilon=\frac{\Delta k}{k} \cdot 100 \% \cong 17 \%
$$


Confidence interval:

$$
k=(1.0-1.4) \cdot 10^{-23} \frac{\mathrm{J}}{\mathrm{K}} .
$$

Thus, the theoretical value $\mathrm{k}=1.38 \cdot 10^{-23} \mathrm{~J} / \mathrm{K}\langle\mathrm{falls} »$ in the confidence interval, although the measurement error is quite significant.

The experimental setup we use is «assembled» manually and there is no need to rely on the best result [5].

The systems considered in molecular physics are statistical. When analyzing them, the corresponding mathematical apparatus is used: mathematical probability, probability theorems, the concept of averages, theorems of averages, ergodic hypothesis, deviations from the mean [6].

Neutral atoms and molecules obey classical statistics. This is the statistics of distinguishable particles energy of which varies continuously. The main Maxwellian distribution is the velocity or kinetic energy distribution of molecules and the Boltzmann distribution of potential energy molecules in a conservative force field, in particular in the field of the Earth. It is known that they received experimental confirmation several decades after the creation of corresponding theories. We are talking about the experiences of Stern and Perrin.

The velocity distribution of molecules (based on Stern's experiments) and the study of the distribution of Brownian particles in a gravity field and the determination of Boltzmann constant (based on Perrin's experiments) can only be considered using virtual laboratory works in our conditions, they were studied experimentally in due time in the periods from 1906 to 1908 (Perrin's experience) and from 1920 to 1929 (Stern's experience). These experiments are described in educational literature and are well known.

The virtual laboratory work on the Maxwell distribution was carried out in accordance with the MU proposed in [7]. Temperature $1500 \mathrm{~K}$, and the angular velocity of rotation of the cylinder $1000 \mathrm{rad} / \mathrm{sec}$ were introduced. The velocities of the particles were set in arbitrary units from 0 to 25 with a step of $50,59 \mathrm{~m} / \mathrm{sec}$. Results are presented using a histograms. The experiments were repeated for another temperature $(3000 \mathrm{~K})$ with a speed step of $71.34 \mathrm{~m} / \mathrm{sec}$.

The results of measurements and calculations are presented in Figure 1.

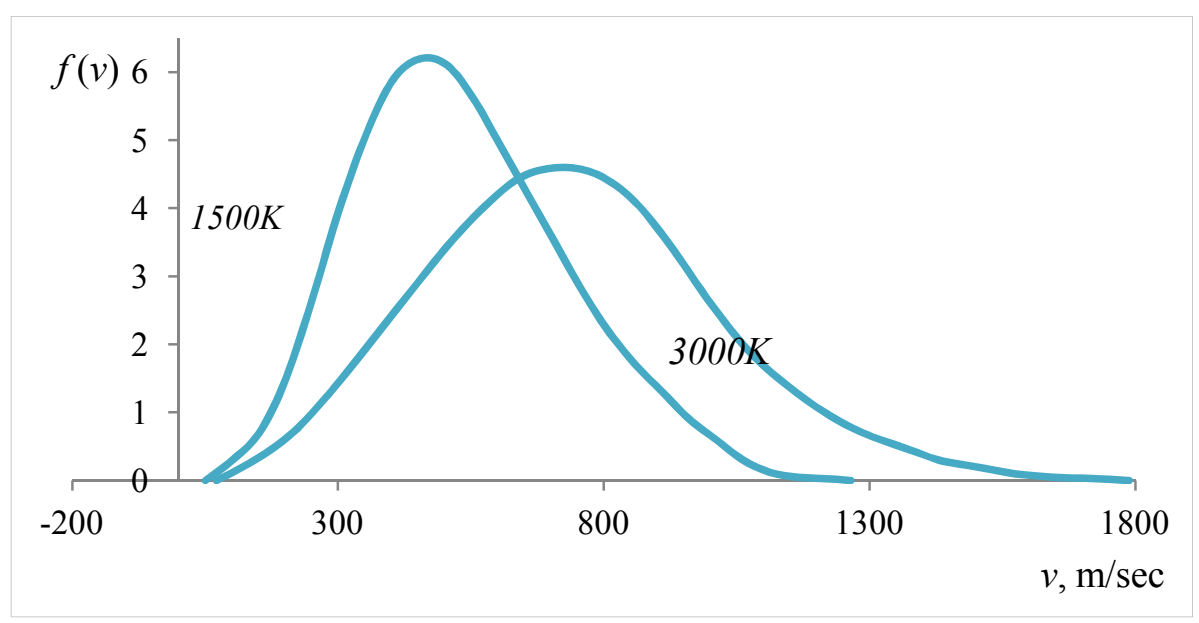

Figure 1. Maxwell distribution of molecules on velocities

The most probable velocities were calculated: in the first case $346 \mathrm{~m} / \mathrm{sec}$, in the second $-1264 \mathrm{~m} / \mathrm{sec}$.

In addition, students were asked to calculate the molar mass of the filament coating in the experimental setup. Calculations showed that we are talking about silver. It is known from literary sources that silver was used in the first installations of Stern.

On the experiments of Perrin based virtual laboratory work devoted to the study of the distribution of Brownian particles in the field of gravity of the Earth. In the well-known experiments of Perrin, Brownian particles were used in the form of balls (these are gummigut particles) suspended in the environment. In this case, two more conditions were fulfilled: in each experimental series, particles of the same size were used, for which Perrin designed and practically used microcentre. This, firstly, and secondly, the density of the substance of Brownian particles and the environment must be chosen so that the Brownian particles are sus- 
pended. In different series of experiments different problems were solved. In one of them, the Avogadro number was calculated on the basis of the Boltzmann distribution. In our chosen laboratory work, the Boltzmann constant was determined.

As an environment was used water $\left(\rho_{0}=10^{3} \mathrm{~kg} / \mathrm{m}^{3}\right) ;$ petrol $\left(\rho_{0}=0,88 \cdot 10^{3} \mathrm{~kg} / \mathrm{m}^{3}\right) ;$ alcohol $\left(\rho_{0}=790 \mathrm{~kg} / \mathrm{m}^{3}\right)$. The density of the substance of Brownian particles was set: $\left(\rho_{0}=1,1 \cdot 10^{3} \mathrm{~kg} / \mathrm{m}^{3}\right)$.

To determine the diameter of Brownian particles, a chain is built from them and the total length is measured. The diameter of Brownian particles is $\mathrm{d}=0.5 \mathrm{mcm}$. The number of Brownian particles was determined at zero height and at altitudes: $30 \mathrm{mcm} ; 60 \mathrm{mcm}$.

Based on the Boltzmann formula for Brownian particles in a layer of volume $S \Delta h$ :

$$
\Delta N=n_{0} e^{-\frac{\Delta \rho V g h}{R T}} S \Delta h
$$

where $\mathrm{n}_{0}$ - concentration of Brownian particles at zero height,

$\Delta \rho$ - density difference between Brownian particles and the environment;

$\mathrm{V}$ - Brownian particle volume.

Hence, the Boltzmann constant was determined:

$$
k=\frac{\Delta \rho V g h}{T \ln \frac{n_{0}}{n}},
$$

The results are:

in water: $\mathrm{k}=1.33 \cdot 10^{-23} \mathrm{~J} / \mathrm{K}$;

in petrol: $\mathrm{k}=1.17 \cdot 10^{-23} \mathrm{~J} / \mathrm{K}$;

in alcohol: $\mathrm{k}=1.97 \cdot 10^{-23} \mathrm{~J} / \mathrm{K}$.

The best result in measurements in water (it was in this environment that Perren's original experiments were conducted), the worst of all is in alcohol.

But in any case, the result is better than the contact definition of the Boltzmann constant.

One of the experimental bases and experimental confirmations of the foundations of the molecularkinetic theory is the Brownian motion. Therefore, of particular interest is the virtual laboratory work on the determination and analysis of the average free path of Brownian particles [8].

It is known that

$$
<\lambda>=\frac{1}{\sqrt{2} \pi d_{e f f}^{2} n}
$$

where $\langle\lambda\rangle$ - average length of free path;

$<\mathrm{d}_{\mathrm{efP}}>$ - effective diameter (for molecules);

$\mathrm{n}$ - their concentration. follows:

The average number of collisions of molecules with other molecules per unit of time is determined as

$$
<z>=\frac{<v>}{<\lambda>},
$$

where $<\mathrm{v}>$ - average velocity of chaotic particle motion.

Enter the number of particles equal to 25 , and the diameter of 350 conventional units at a temperature of $\mathrm{T}=1000 \mathrm{~K}$.

Conduct 5-6 experiments, changing the diameter from 350 to 100 conventional units, and the number of particles from 25 to 5 .

Build graphs of the dependence of $\langle\lambda>$ on $d$ with $n=$ const (Fig. 2) and $<\lambda>$ on $n$ with $d=$ const (Fig. 3). 


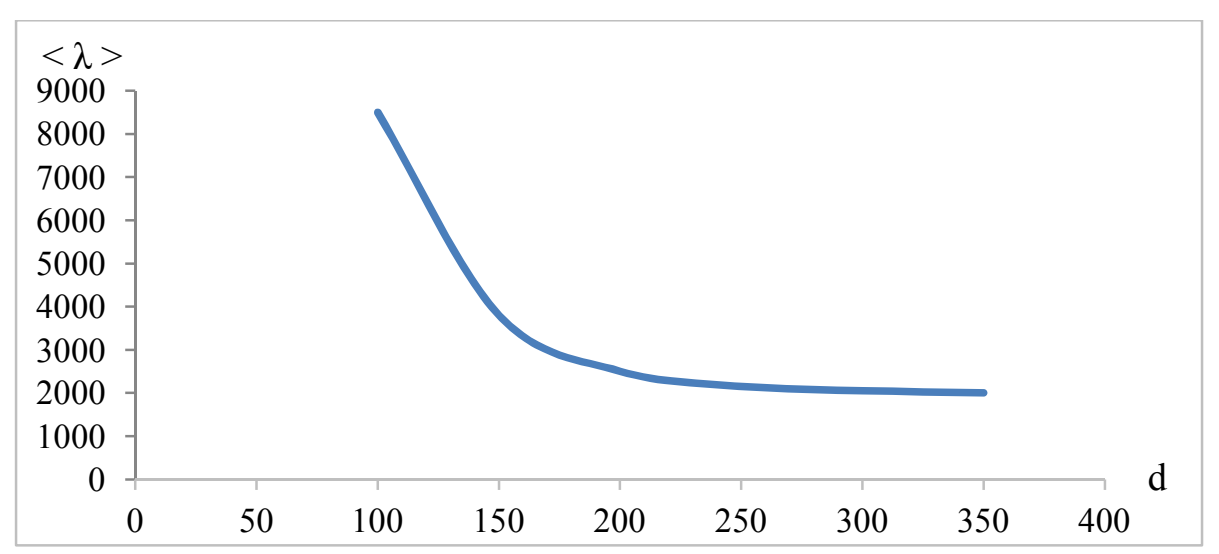

Figure 2. Dependence of average length of free path on the particle diameter at $n=$ const

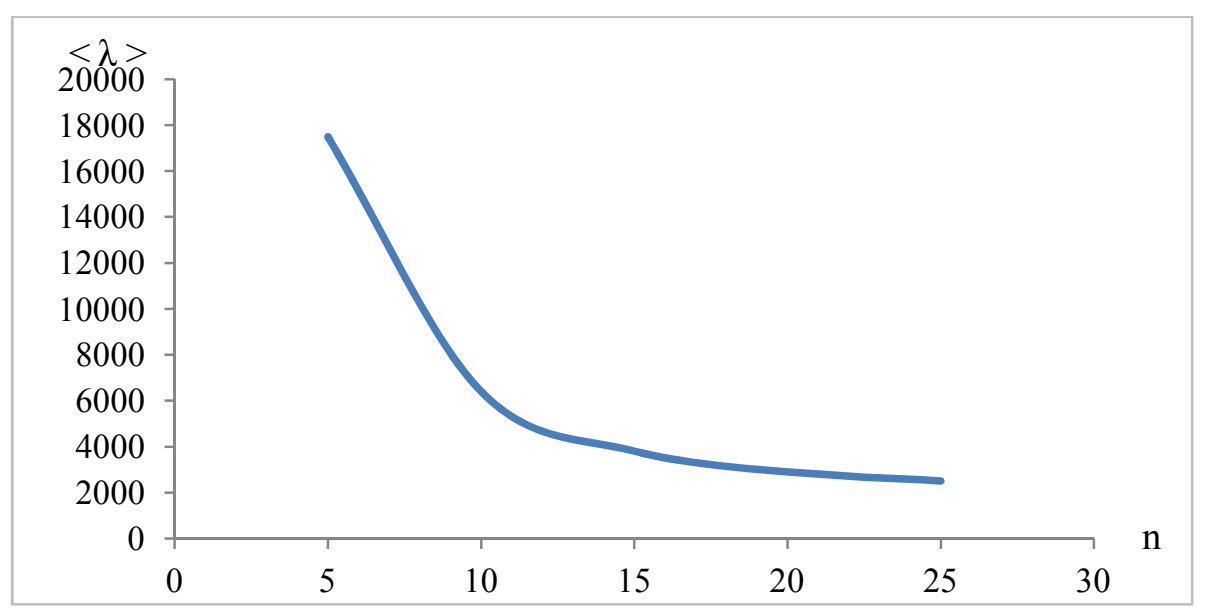

Figure 3. Dependence of average length of free path of particles on their concentration atd $=$ const

Of particular importance in the study of molecular physics are transfer phenomena. Let us stay on one classic laboratory work: «Determination of the coefficient of internal friction of a fluid by the Stokes method». The experimental setup is a long cylindrical glass vessel filled with glycerin. Studying the movements of solid balls of small radius, which are affected by the force of gravity, the buoyant force and the force of internal friction, determined by the Stokes formula.

Work is quite classical, with proper contact and its implementation gives the value of the coefficient of viscosity of glycerol, corresponding to the theoretical.

Work on the modernization of the physics laboratory in molecular physics has been carried out for several years, but it was carried out not systematically, and most importantly, without the active involvement of virtual laboratory work.

The result of the work will be the creation of a physical practicum, covering all basic sections of molecular physics and the publication of relevant guidelines.

\section{References}

1 Матвеев А.И. Молекулярная физика / А.И. Матвеев. - М.: Высш. шк., 1987.

2 Иродов И.Е. Физика макросистем. Основные законы / И.Е. Иродов. - М.; СПб.: Лаборатория баз знаний, 2001.

3 Кикоин И.К. Молекулярная физика / И.К. Кикоин, А.К. Кикоин. - М.: Наука, 1976.

4 Телеснин Р.В. Молекулярная физика / Р.В. Телеснин. - М.: Высш. шк., 1973.

5 Физический практикум; Механика и молекулярная физика / под ред. В.И. Ивероновой. — Ч. 1. — 1988.

6 Ильина Л.Ф. Физика. Механика и молекулярная физика: учеб.- метод. пос. / Л.Ф. Ильина, Л.С. Бадаева. - Караганда: Изд-во КарГУ, 2014.

7 Толстик А.М. Виртуальные лабораторные работы / А.М. Толстик. — Томск: Томск. ун-т, 2007.

8 Жанбырбай Е.Р. Система организации СРС и СРСП на примере раздела «Явления переноса» / Е.Р. Жанбырбай, Л.Ф. Ильина // Вестн. Караганд. ун-та. Сер. Физика. — 2018. - № 3 (91). - С. 93-102. 


\title{
Л.Ф.Ильина, А.С.Каюмова, Е.Р.Жаңбырбай, М.М.Болатбекова \\ Жоғарғы оқу орны курсында молекулалық физика бойынша физпрактикумның модернизация мәселесі
}

\begin{abstract}
Мақала физика және нанотехнологиялар кафедрасында молекулалық физика бойынша физикалық практикумды жаңғыртуына байланысты авторлардың жұмыстарының нәтижелерін талдауға арналған. Мұндай физикалық практикумды сапалы орындау үшін виртуалды зертханалық жұмыстарды пайдаланбау мүмкін емес, бірақ түйіспелі зертханалық жұмыстар да қажет. Сонымен қатар кейбір зертханалық жұмыстарды түйіспелі және виртуалды түрде орындау қажет. Мақалада газ заңдары мен әмбебап газ тұрақтысы және Больцман тұрақтысын анықтау бойынша жұмыстардың мәні баяндалған; статистика бойынша үш виртуалды жұмыс және тасымалдау құбылыстары бойынша бір түйіспелі зертханалық жұмыс талданды. Жұмыстар алдын ала талданып, оқытушылар мен инженерлер деңгейінде, одан кейін жалпы физика курсында, сондай-ақ тиісті бейіндегі арнайы курстарда әртүрлі топтарда жүргізілді. Кейбір бөлімдер бойынша дипломдық жұмыстар мен магистрлік диссертациялар орындалды; түрлі деңгейдегі конференцияда баяндамалар ұсынылды; мақалалар мен оқу-әдістемелік құралдар жарияланды.
\end{abstract}

Кілт сөздер: максвелл түрлендіруі, броундық қозғалыс, түйіспелі және виртуалды зертханалық жұмыстар, тасымалдау құбылыстары.

\section{Л.Ф. Ильина, А.С. Каюмова, Е.Р. Жанбырбай, М.М. Болатбекова \\ К модернизации физпрактикума по молекулярной физике в вузовском курсе}

\begin{abstract}
Статья посвящена анализу результатов работы авторов по модернизации физпрактикума по молекулярной физике на кафедре физики и нанотехнологий физико-технического факультета. Качественная постановка такого физпрактикума невозможна без использования виртуальных лабораторных работ, но контактные лабораторные работы также необходимы. Более того целесообразно некоторые лабораторные работы выполнять как контактно, так и виртуально. Авторами изложена суть работ по газовым законам и определению универсальной газовой постоянной и постоянной Больцмана; проанализированы три виртуальные работы по статистической физике и одна контактная лабораторная работа по явлениям переноса. Работы предварительно анализировались и выполнялись на уровне преподавателей и инженеров, затем студентами, причем разных групп как в курсе общей физики, так и в спецкурсах соответствующего профиля. По некоторым разделам выполнялись дипломные работы и магистерские диссертации; представлялись доклады на конференциях разных уровней; опубликованы статьи и учебно-методическое пособие.
\end{abstract}

Ключевые слова: максвелловское распределение, броуновское движение, контактные и виртуальные лабораторные работы, явления переноса.

\section{References}

1 Matveev, A.I. (1987). Molekuliarnaia fizika [Molecular physics]. Moscow: Vysshaia shkola [in Russian].

2 Irodov, I.E. (2001). Fizika makrosistem. Osnovnye zakony [Physics of macrosystems. Basic laws]. Moscow-Saint-Petersburg: Laboratoriia bazovykh znanii [in Russian].

3 Kikoin, I.K., \& Kikoin, A.K. (1976). Molekuliarnaia fizika [Molecular physics]. Moscow: Nauka [in Russian].

4 Telesnin, R.V. (1973). Molekuliarnaia fizika [Molecular physics]. Moscow: Vysshaia shkola [in Russian].

5 Iveronova, V.I. (1988). Fizicheskii praktikum. Mekhanika i molekuliarnaia fizika [Physical practicum. Mechanics and Molecular physics]. Moscow: Nauka [in Russian].

6 Ilina, L.F., \& Badaeva, L.S. (2014). Fizika. Chast 1. Mehanika. Molekulyarnaia fizika. [Physics. Part 1. Mechanics. Molecular physics]. Karaganda: Izdatelstvo Karahandinskoho hosudarstvennoho universiteta [in Russian].

7 Tolstik, A.M. (2007). Virtualnye laboratornye raboty [Virtual laboratory works]. Tomsk: Tomskii universitet [in Russian].

8 Zhangbyrbaj, Ye.R., \& Ilina, L.F. (2018). Sistema orhanizatsii SRS i SRSP na primere razdela «Yavleniia perenosa» [The system of organization of the IWS and IWST studies by the example of «Transport phenomena»]. Vestnik Karahandinskoho universiteta. Seriia fiziki - Bulletin of the Karaganda University, Physics Series, 3(91), 93-102 [in Russian]. 